\title{
Design Theory and the Australian Tula Adze
}

\author{
$\boldsymbol{\Delta} \cdot \boldsymbol{\Delta} \cdot \boldsymbol{\Delta}$ \\ TRUDY DOELMAN AND GRANT W. G. COCHRANE
}

\section{INTRODUCTION}

The tUla (OR TUHLA) ADZE is a unique composite tool, invented and adapted to arid zone Australia and used through the late Holocene until recent times (Veth et al. 2011). A wealth of ethnographic descriptions and archaeological studies have already provided a strong corpus of information about the manufacture and use of this implement. Our goal here is to explain why Aboriginal toolmakers manufactured it according to relatively rigid design specifications over large expanses of space and time. We do this through a reexamination of the ethnographic and archaeological evidence and the application of design theory. We will argue that tula adzes were designed to be reliable implements during a period of environmental unpredictability. However, the economic benefits of these reliable design features cannot be measured merely in terms of greater efficiency in resource harvesting. More significantly, they helped to ensure the consistent production of high-quality trade items that were crucial to the establishment and maintenance of cooperative relationships between social groups.

\section{DESIGN THEORY}

Design theory draws upon concepts employed by modern-day design engineers in order to explain why particular design choices were made. Its application to the material culture of past hunter-gatherers was first proposed by Bleed (1986) and subsequently developed by a number of other researchers (e.g., Eerkens 1998; Nelson 1991; Torrence 2001). It is important to stress that in most archaeological contexts, design theory is only one part of a more complex theoretical process. Design theory is not used to simply reconstruct past tool designs. This must instead be achieved through the prior application of other forms of theory (such as Middle Range Theory) on the available strands of evidence. Once the past tool design has been reconstructed, design theory draws upon principles of rational optimization to explain why the design of the tool was chosen over other alternatives. To provide this explanation, design theory also considers the environmental context of tool manufacture, use, and discard.

Trudy Doelman and Grant W. G. Cochrane are both Research Associates in the Department of Archaeology, University of Sydney, Australia. 
A fundamental axiom of design theory, which some researchers might find contentious, is that all tools are the product of design:

Observations by anthropologists suggest that primitive hunters are ... rational in the area of technology in that they make and use well-crafted, carefully designed tools. In that sense, the weapons of primitive hunters can be compared to modern industrial systems like assembly lines, semi-trucks or the space shuttle. . . All technical systems result from a design process. This may be either explicit or implicit, but in either case the designer selects from the available alternatives to create a solution to an identified problem. (Bleed 1986:738)

Holdaway and Douglass (2012) recently noted that ethnographic accounts of Australian Aboriginal stone tool production occasionally describe very deliberate processes, but more frequently employ terms such as "indifferent," "casual," and "random," especially when describing core reduction. Some might therefore take the view that notions of design are usually inappropriate to the characterization of Australian stone tool technologies. We hold the view that even the simplest tool is the product of some preformed mental concept, so at least theoretically all material culture could be subjected to design theory.

This does not imply that artifacts should neatly fall into standardized groupings. Some designs may be the one-off creation of an individual to fulfill a specific purpose. Some may only focus on one or two crucial attributes of the tool, such as edge angle or weight, and allow for considerable variation in other attributes. Manufacturing errors or lack of precision also serve to create variation in tool morphology. Artifact assemblages also contain many tools whose form has been altered during or after use, along with an abundance of manufacturing waste. At the other end of the spectrum, some artifacts may be the product of designs that were extremely precise, restricted to specialized artisans, and maintained across generations. It is in such cases that standardized artifact morphologies are most likely to be evident in the archaeological record.

It follows that while standardized tool types are not the only tools that may be analyzed using design theory, they will usually be the most suitable because it is easier to infer their design. This is because they are more amenable to Middle Range processes such as replication and there are more likely to be consistent ethnographic accounts of their manufacture and use. The tula adze is a good example of a tool that falls into this category.

\section{RELIABLE DESIGN SYSTEMS}

Bleed (1986) originally used the concept of "design systems" in order to classify designs into groups that represent particular strategic approaches. It was in this context that he defined "reliable" and "maintainable" design systems (Bleed 1986:738-740). Nelson (1991) sought to incorporate design within the broader theoretical conceptualization of technological organization. To some extent she drew upon Bleed's concepts but eschewed the term "design systems" and provided a different definition of maintainable designs. She also defined three additional design categories: flexible, versatile, and transportable. All of these design categories are idealized concepts, so a particular tool design does not necessarily fall neatly within any one category (Bleed 2002 : 101). Design theory provides guidelines for assessing the extent to which a design is characterized by each of these categories and provides a rationale for understanding the circumstances under which particular categories are advantageous. 
Table i. Characteristics of Reliable Design Systems (after Bleed i986)

FEATURES OF RELIABLE DESIGN SYSTEMS

1. Overdesigned components (parts made stronger than they minimally need to be)

2. Understressed (system used at less than full capacity)

3. Parallel subsystems and components (redundant and standby)

4. Carefully fitted parts and generally good craftsmanship

5. Generalized repair kit including basic raw materials (to affect any repair)

6. Maintained and used at different times

7. Maintained and made by specialist

We will be providing evidence in this paper that the design of the tula adze falls within Bleed's definition of a reliable design system. Elements of the tula adze design could also be interpreted as falling within other design categories, but for the sake of clarity we will limit discussion of this to a later part of the article. Our emphasis will be on demonstrating the affinity of the tula design with the typical characteristics of reliable design systems and determining why this strategy was employed. It is therefore important to establish what constitutes a reliable design system. A reliable design system is one that provides efficiency by maximizing the amount of time that the tool is available to do its job. It does this by assuring that the tool will be able to function during the times when it is needed. This can be contrasted with a maintainable design system, which achieves a similar objective by being amenable to quick repair if damage occurs (Bleed 1986).

In Table 1 we have reproduced the list of design characteristics that Bleed (1986) regarded as typical of reliable systems. In essence these characteristics serve to minimize the risk of damage during use. Most of them imply high production costs. Because of these costs, reliable systems will only be optimal in certain conditions, such as when the costs of failure are even higher than the costs of production. Situations where the use of the tool conforms to a predictable schedule are also suitable for reliable systems because a clearly defined downtime can be used for conducting maintenance activities, thus ensuring functionality during times of need.

Bleed (1986:741-744) clearly felt that design theory would be most applicable to hunting weapons and provided ethnographic examples of reliable and maintainable design systems in these contexts. His example of a reliable system referred to the equipment of Nunamiut hunters who obtained the majority of their annual food supply from 30 days of caribou hunting during highly predictable spring and fall migrations. In this situation the task was specialized, repetitive, and predictable and the implications of failure were dire.

\section{DEFINING THE TULA ADZE}

The tula adze was a composite tool that consisted of a flaked stone (the tula adze flake) using a hafting medium (usually resin) for attachment to a thick, smoothed wooden handle that often had multiple components. All tula adzes are characterized by a hafting arrangement whereby the proximal end of the flake, including the platform, is fitted in the hafting resin and the opposite distal end of the flake forms the working edge. In archaeological contexts the stone component of the tula adze is usually the only part that has been preserved. The vast majority of these archaeological tula adze 


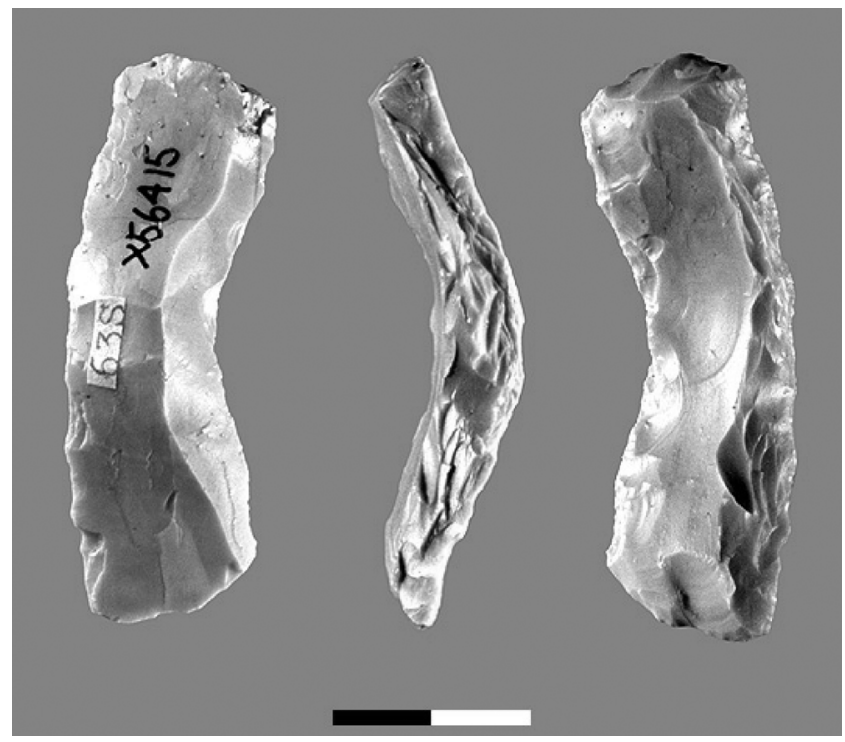

Fig. 1. Ventral view of a tula slug (left); step retouch on the distal end of a tula slug (center); dorsal view of a tula slug (right) (Holdaway and Stern 2004: figure 6.25.1).

flakes are known as slugs, which is the characteristic form that the tula adze flake takes after it has been worked and resharpened to the point of exhaustion (Fig. 1).

The tula adze should not be confused with the burren adze, which is hafted laterally (Tindale 1965:138, 159-160). The burren and tula adze, Tindale (1965:160) argues, have "two entirely different procedures in manufacture which probably have had entirely different histories of origin." Considerable differences occur in the ways these two types of adze flakes were made, hafted, and used (Tindale 1965:159-160). Numerous observations have been made of the manufacture of random flakes that were selected, hafted laterally, and then retouched to make the burren (Hayden 1979:12, 23; Mountford 1941:315; Thomson 1964:416-417; Tindale 1965:138, 160). As Mulvaney (1969:73-74) points out, burrens are "hafted chisel-like tools whose cutting edges consist of simple untrimmed or irregular retouched flakes, embracing a broad morphological range, which lack the standardised tula features." The burren was defined as a multi-functional "general cutting tool" for tasks such as cutting meat and sharpening and making spears (Tindale 1965:154).

The regional distribution of the tula adze has been summarized by previous archaeologists including Kamminga (1985), Flood (1993), McNiven (1993), and Veth et al. (2011). Figure 2 shows a very generalized map of the distribution of tula adzes. Note that the use of tula adzes is yet to be recorded in some locations within the arid zone such as the southern part of the GreatVictoria Desert (Hayden 1979:12, 23) and the Musgrave Ranges and Mount Davies in far northern South Australia (Mountford 1941:315; Tindale 1965).

\section{THE ETHNOGRAPHY AND ARCHAEOLOGY OF THE TULA ADZE}

As we indicated above, to characterize the design of the tula adze it is first necessary to glean information about how materials were procured, how the adze was manufactured, and the manner in which it was used, maintained, transported, and discarded. In this section we examine ethnographic and archaeological evidence to shed light on 


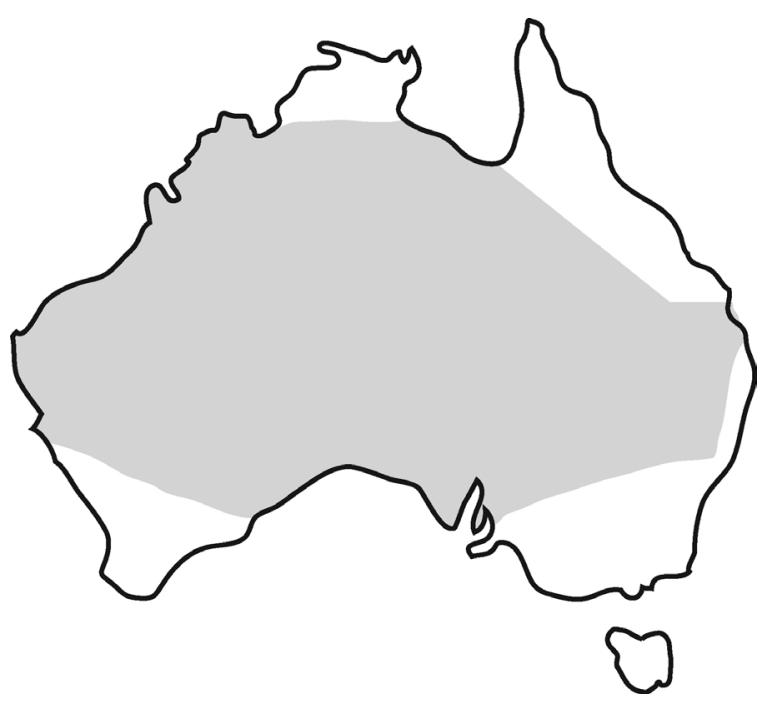

Fig. 2. Regional distribution of the tula adze (after Veth et al. 2011:7).

these questions. Our ethnographic references are drawn from a variety of locations so we may identify common trends in manufacture and usage and mitigate inaccuracies or biases that may underlie individual sources. We also draw from a range of archaeological references, including our own archaeological studies in western New South Wales.

\section{Materials and Their Procurement}

The Handle-Local hardwoods that could be worked up free from splinters were usually selected for the manufacture of thick, smoothed wooden handles (Horne and Aiston 1924 : 101). The handle was either curved or straight, could be up to $60 \mathrm{~cm}$ in length, and was invariably made from a hardwood such as gidyea (Acacia homalophylla) or mulga (Acacia aneura) (Aiston 1929:44-45; Etheridge 1891:41; Roth 1897:101; 1904:17, 20; Spencer 1928:501; Spencer and Gillen 1912:371). Often the handle served multiple purposes. For example, a different tool might be mounted at the opposite end or the handle itself could also function as a spear thrower. Sometimes a tula adze flake was hafted on each end of the handle (Roth 1904:20; Spencer 1928:501; Spencer and Gillen 1912:371) (Fig. 3).

The Resin-The preferred adhesive was a "spinifex" resin derived from a number of perennial grass species within the genus Triodia that were common throughout much of the Australian arid zone (Pitman 2010; Sheridan 1979). Triodia resins were highly valued because they were among the strongest and most malleable adhesive substances known in indigenous Australia. People sometimes traveled long distances to find suitable plants; the resin was often acquired through trade when not available locally (Latz 1995:66-67; McBryde 1987:264; Pitman 2010:55). Adhesives for tula hafting were also manufactured from a variety of other resins or gums, especially when Triodia resins could not be obtained (e.g., Aiston 1929:44-45; Cleland 1957:160). In sum, the ethnographic evidence suggests that the strongest available adhesive was utilized for tula adze production. 


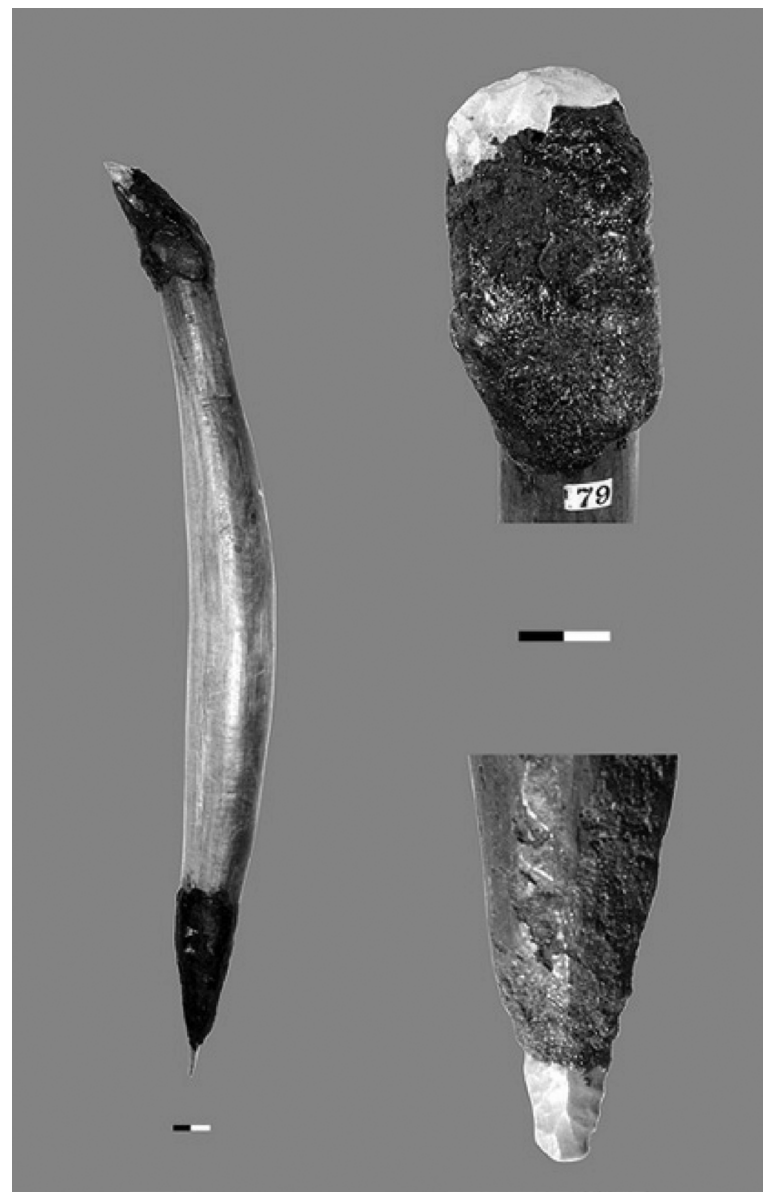

Fig. 3. A hafted tula adze (Holdaway and Stern 2004: figure 6.23.1).

The Stone-The initial selection of suitable stone for the tula adze flake was always made carefully (Campbell and Edwards 1966: 194; Noone 1949:111; Roth 1904:16). Tula flakes were typically made near quarries by practiced craftsmen who specialized in making stone tools (Horne and Aiston 1924:105-106; Noone 1949:112). The quarries had abundant, high-quality material needed to manufacture tula flakes.

A good archaeological example of this lithic selectivity can be gleaned from our work in Sturt National Park in western New South Wales. In the bluffs of the Mount Wood Range there are many silcrete outcrops of varying quality. Surrounding the bluffs, the landscape is dominated by pavements of closely packed subspherical cobbles (or gibber) that stretch across the plains, making the area an almost continuous but heterogeneous source of silcrete raw material.

To distinguish the quality of the available material, we divided the silcrete into three groups following definitions made by Wopfner (1978) and Sullivan and Simmons (1979). Most of the silcrete in the region falls into two main groups: Group II or Group III (Doelman 2005). Silcrete derived from sandstone (Group II type) is clast-dominated with individual, quartz grains silicified together. This group was subdivided into fine and medium grained depending on the diameter of the quartz grains and degree of size-sorting. The size of the quartz grains in the parent rock dictates the 
quality of silcrete. The highest quality stone is a microcrystalline or Group III silcrete. It has a homogenous appearance as no individual quartz grains can be seen under a hand lens with $10 \times$ magnification. In addition, fracture toughness experiments comparing the Group III and Group II medium-grained silcrete indicate the higher compressive and tensile strength of Group III microcrystalline silcrete (fully described in Doelman et al. 2001).

An on-site attribute analysis of surface lithic scatters was conducted at two locations in the Stud Creek Catchment, Stud 1 and Stud 2 (Cochrane 1998, 1999; Holdaway et al. 2004). Holdaway et al. (2004) suggest that these surface scatters reflect a late Holocene occupation of the area based on the radiocarbon dates, tool typology, and geomorphological indicators. In archaeological contexts the stone component of the tula adze is usually the only part that has been preserved. The vast majority of these archaeological tula adzes are known as slugs, which refers to the characteristic form tula flakes take after they have been worked and resharpened to the point of exhaustion (Fig. 1). A total of 227 tula adzes (mostly slugs) were identified among much larger assemblages of stone artifacts recorded at the Stud Creek locations. Most of the tula adzes were made from high-quality Group III silcrete $(94.3 \%, n=214)$, indicating that this material type was highly preferred. No other tool type exhibited this degree of raw material selectivity. At Stud 1, for example, 40 percent $(n=290)$ of the scrapers with scalar retouch and 42.6 percent $(n=185)$ with notched retouch were made from Group III silcrete (Cochrane 1998:79-80; Doelman 2008:133). Only 13 tula adzes were made from non-Group III silcrete. Of these, most were made from fine clast silcrete $(n=8)$, a higher quality material than medium clast silcrete $(\mathrm{n}=5)$.

Tula adzes made from poorer quality lithic material occur so infrequently in these assemblages that we believe they reflect unusual departures from the conventional manufacturing process (Cochrane 1998:129-131). Their rarity suggests that the manufacturing of tulas away from known high-quality lithic sources only occurred in unusual circumstances. This claim is supported by the size of these Group II specimens. They are small in maximum length and therefore reworked to some extent before discard but are not as heavily reduced as the Group III tula slugs. While their numbers were small, analysis of their spatial distribution at Stud 1 suggested that they had different patterns of discard from Group III tulas (Cochrane 1998:129-131). Hence we argue that tula adzes of poor quality were quickly replaced when high-quality raw material became available. Some gibber and stream cobbles in the area are composed of Group III silcrete but we estimate that they comprise only about 10 percent of all cobbles (Doelman et al. 2001). Testing a large number of gibber cobbles of a suitable size before one was found of Group III silcrete would have been a time-consuming exercise. There are quarries close to Stud 1 and 2 with ample, large blocks of highquality material (Doelman 2008). In ordinary circumstances, these would have been the most suitable locations for manufacturing tula flakes.

The high selectivity of lithic raw material for tula adze flakes appears to be mainly related to use requirements (Gould 1978: 827-830; Hewitt 1976; Kamminga 1985: 17; Morwood 1981:30; Smith 2006:393-395). At the Native Well sites in the central Queensland highlands, tula adzes were made exclusively from chert rather than the more common fine-grained silcrete (Morwood 1981:30; Webb and Domanski 2008). Mechanical testing conducted by Webb and Domanski (2008) indicated that in many respects the local silcrete was a desirable raw material but it was prone to edge fractur- 
ing because of its relatively low tensile strength and fracture toughness. This implied that it was less suitable for tasks such as working hardwood than microcrystalline chert. Use experiments involving tula adzes made from a variety of raw materials have confirmed that selection of stone for making tulas at Puntutjarpa Rockshelter in the Western Desert strongly favored materials that were most efficient for adzing hardwood (Gould 1978:827-829). It is likely that factors such as the workability of more homogenous material and the ability to carefully control retouch also contributed to the selection of raw material.

\section{Manufacture of the Tula Adze}

Manufacturing the Handle-While the types of handles were variable, considerable effort was usually invested in making them. Once the wood had been cut and the handle had been roughened out, a variety of methods could be employed to bend it to the required shape. If the handle was to serve no other function, it could be shaped by scraping and grinding (Horne and Aiston 1924:101-102). On the other hand, bending wood to manufacture spear-throwers could involve more time-consuming processes such as the application of dry or moist heat or prolonged soaking in water followed by the application of grease and fat (Roth 1897:102). After the wood had been thus prepared, it was further shaped by scraping, adzing, or gouging (Roth 1904:9). After this work had been completed, the implement was often polished with leaves or pumice stone (Roth 1904:9). Spencer and Gillen (1912:371) noted that even plain handles were sometimes ornamented with longitudinal grooves.

Manufacturing the Adhesive-Sheridan (1979) and Pitman (2010) have summarized numerous ethnographic observations of Triodia resin manufacturing by Aboriginal people in the arid zone. While the precise details varied, the process usually involved a number of steps, including: (1) plant collection, (2) threshing, (3) winnowing, (4) adjustment of chaff content, (5) careful application of heat, and (6) aggregation, compaction, and cooling. These different steps were sometimes performed by different groups of people, so the expertise required for producing the ideal resin could have been shared within a community. The production of other adhesives depended upon the particular plant that was utilized, but the process was frequently quite detailed and time-consuming (e.g., Aiston 1929:44-45; Horne and Aiston 1924:102). Triodia and other adhesives employed for hafting tula adzes could be softened and reused by reheating, which aided the rehafting of a new tula flake on to the handle when the old one was exhausted (Horne and Aiston 1924:107). Triodia and other resins were often manufactured in bulk and used for a variety of purposes, so the effort involved in making the resin was not always expended solely for the purpose of tula adze production.

Manufacturing the Tula Flake Blank-Several ethnographers have observed that much care was taken in the flaking and selection of the tula flake blank (e.g., Aiston 1928:127; Horne and Aiston 1924:89-91; Roth 1904:16), leading to the common perception that its morphology was the product of purposive design (Campbell and Edwards 1966 : 190). Tindale $(1965: 160)$ emphasized that "sophisticated techniques" were used to manufacture the tula flake from a systematically prepared core struck at a "carefully chosen point on a prepared platform in such a manner that a potentially discoidal flake is detached." Campbell and Edwards (1966:193-194) noted that the core was pre- 
pared so that a flake with a concavo-convex cross section could be detached. Because tula flake cross sections have also been described as double-convex and plano-convex (Holdaway and Stern 2004:253; Spencer and Gillen 1912:371; 1969:636), it appears that the precise shape of the dorsal surface of the flake blank was not crucial, especially because it could be modified by secondary retouch prior to hafting (Hewitt 1976:30; Moore 2004 : 68). However, the overall size and shape of the flake blank did have a significant impact on its selection. Aiston described how one hundred tula flakes were laid out and only a dozen were selected for manufacture into tula adzes. The "ideal" size was "at least two inches $[5.08 \mathrm{~cm}]$ " in length before retouching (Aiston 1928:127). Flakes with a large bulb were desirable, the more prominent the better.

Archaeologists have used a combination of methods including refitting, replication, flake scar analysis, and technological typologies to determine more precisely how tula adze flakes were manufactured. Several core reduction strategies have been described yet the resulting flakes are largely similar in form. These reduction strategies seem to have been dictated by the size and shape of the core body. Witter (1992:67-69) recognized that three core bodies were used to manufacture tula flakes in northwestern New South Wales: (1) large flakes, where it is possible to see the original ventral surface of the flake on a tula flake's platform; (2) gibber cobbles, where resulting tula flakes have a smooth, cortical platform; and (3) blocks/angular fragments obtained from outcrops, where resulting tula flakes typically have faceted platforms. Another reduction strategy was described by Moore (2004) based on a study conducted in Camooweal, northwestern Queensland. Here the selection of only flat to lenticular chert cobbles was an important part of the strategy. The same core face was used repeatedly to remove tula flakes across the thickness of the cobble, causing the core to retreat along its length but maximizing the number of flakes removed from one cobble. The resulting flakes were all of the same size with a distinctive gull-wing platform due to the presence of a concave core surface produced from the previous removal. Interior platform angles were usually greater than 120 degrees.

Independent of the reduction strategy, the core had to be struck precisely, using a hard hammerstone and high-velocity force, well back from the platform to produce a short, thick flake with a wide platform. The direction of the blow was close to 90 degrees to the platform rather than the 60-80 degrees range that applies to most direct percussion flaking (Akerman 2005). Ideally the angle between the core face and the core platform was about 60 degrees (Hewitt 1976:31).

Successful manufacture of a tula flake depended on the skill of the knapper. Moore (2004) suggests that a high failure rate occurs in the manufacture of tula flakes based on his knapping experiments in which as many as 70 percent broke longitudinally through the bulb of percussion (siret break). In response, Akerman (2005) argues that such errors were minimized because tula flake manufacture was undertaken by skilled knappers who precisely calculated the placement and velocity of each removal. Ideally these flakes needed a thick platform or a siret break would occur, however.

Shaping the Tula Flake - In his ethnographic descriptions of toolmaking in western Queensland, Roth (1904:17) observed that once a suitable tula flake had been struck from a core and selected for use, the distal end of the flake was usually shaped into a semicircle back to the bulb, until only the bulbar portion remained. If the distal end was relatively thin, the flake was supported on an anvil. As retouching began to reach 
the external limits of the bulb, a lighter hammerstone was used to prevent accidental breakage of the flake. Finally, any serrations or irregularities in the future cutting margin were flaked off by sharply striking them with a wooden boomerang or an iron tomahawk. The resulting working edge was curved in plan. Variations to this procedure, such as the use of the teeth for retouching, have been observed in other regions (Gould et al. 1971:157; Horne and Aiston 1924:89; Spencer and Gillen 1969:636). Roth $(1904: 17)$ also noted that the platform was thinned on the dorsal surface prior to being hafted. Hiscock (1988) has provided evidence to support these observations from the Mucklandama Creek 6 cache, also in western Queensland, which contained 50 artifacts that were interpreted to be unused tula flakes at different stages of preparation. In particular, this analysis confirmed that platform thinning was a part of the retouching process and that the resulting “overhang removal" scars (Hiscock 1988:6365) were not a remnant of platform preparation prior to flake detachment (cf. Flenniken and White 1985:142-143). Moore (2004:68) has suggested that this process of platform thinning often focused on the thick outer margins of gull wing platforms. Because the resulting flake scars often extended well down the dorsal surface, they may have been designed to flatten the concave dorsal surface of the flake.

It has been argued that the characteristic retouching of the tula flake was designed not only to provide a curved edge in plan, but also a U-shaped edge profile (enhanced by the curvature of the bulb of percussion) (Kamminga 1982:76-77; Moore 2004:70-71; Sheridan 1979:24). These two vectors of curvature intensified both the accuracy of the blow and the concentration of force. The relatively small contact area of the edge ensured that impact stresses were localized and evenly distributed through the haft. With slight rotation of the flake in the haft, use could be equally spread across the wide, curved edge.

Tula Flake Dimensions-Flenniken and White (1985:142) have noted that variation in the size or other morphological traits of tula flakes becomes more pronounced if the available raw material is of poor quality. Nevertheless, most of the evidence indicates that tula flakes are usually quite standardized in their dimensions, especially within the context of individual sites. A good demonstration of this comes from the data provided by Hiscock (1988) from the Mucklandama Creek 6 cache and nearby surface artifacts.

Included in the cache were 33 artifacts that were interpreted as fully prepared but unused tulas. They provide an ideal context for assessing standardization. The coefficient of variation $(\mathrm{CV})$ is often used by archaeologists as a measure of standardization. $\mathrm{CV}$ is the ratio of the standard deviation to the mean, multiplied by 100, and expressed as a percentage. Because it factors in the influence of the mean, it essentially represents variability scaled to magnitude. On a scale of $\mathrm{CV}$ values, the lower values represent greater constraint on variation and are thus a good indication of standardization. A random uniform distribution, in which all values are possible, has been demonstrated to have a CV of 57.7 percent. Deliberate attempts to produce dimensions that conform to a standard would be expected to produce $\mathrm{CV}$ values considerably lower than this (Eerkens and Bettinger 2001).

Table 2 shows CVs for the length, width, and platform width and thickness of the 33 cached tulas. The CVs suggest that these tulas were manufactured to conform to quite precise dimensional standards. The CVs for width, platform width, and platform thickness were then compared with those of 58 worn tula flakes that had been dis- 
Table 2. CV and D’ad Values for Various Dimensions of Mucklandama Creek 6 Tula ADZES

\begin{tabular}{lccc}
\hline TULA ADZE DIMENSIONS & CACHED CV & SURFACE CV & D'AD \\
\hline Percussion length $(\mathrm{mm})$ & 17.4 & & \\
Percussion width $(\mathrm{mm})$ & 15.0 & 18.6 & $1.84 ; \mathrm{p}=0.18$ \\
Platform width $(\mathrm{mm})$ & 22.9 & 21.2 & $0.31 ; \mathrm{p}=0.58$ \\
Platform thickness $(\mathrm{mm})$ & 31.2 & 26.7 & $0.99 ; \mathrm{p}=0.32$ \\
\hline
\end{tabular}

$\mathrm{CV}=$ Coefficient of variation; D'AD = Feltz and Miller's D'AD statistic.

carded in the vicinity of the cache (CV for length was not calculated because it was expected that this would be affected by use). Feltz and Miller's (1996) D'AD statistic is a robust formula for significance testing of CVs (Eerkens and Bettinger 2001 : 498-499), so D'AD values were calculated to determine if there were significant differences between cached and surface tulas (Table 2). Even at a 90 percent confidence level there was no significant difference between the assemblages for these dimensions. In fact, the platform dimensions were slightly more constrained in the surface sample. This suggests that the standardization not only applies to the cached tula flakes but to the broader assemblage of tula flakes found at the site.

Assembling the Tula Adze-All tulas are characterized by a hafting arrangement whereby the proximal end of the flake, including the platform, is fitted in the haft and the opposite distal end of the flake forms the working edge. As noted above, the handle may vary in form and serve other functions, but the adze flake was always hafted by inserting it firmly into a ball of sticky resin that had been molded onto the end of the handle (Horne and Aiston 1924:102; Roth 1904:17; Spencer and Gillen 1912:371). Sometimes tula flakes were hafted at both ends and sometimes other tool types were hafted at the opposite end of the handle (McCarthy 1976:31; Roth 1897:101; 1904 : 20; Spencer and Gillen 1912:371). Handles were not prepared with slots to accommodate the flake. In fact, Roth $(1904: 20)$ noted that in the hafting that he witnessed in western Queensland, care was taken to ensure that the wood of the handle did not come into contact with the stone. Horne and Aiston's (1924:102) observations in Central Australia suggest that the base of the flake was pushed into the resin until it just rested on the end of the handle. Either way, flakes were immersed deeply into the resin so that the visible working part of the implement was only about one centimeter in length (Spencer and Gillen 1969:637). Given that the resin was normally very strong, this practice ensured that the tool could withstand the jarring that occurred during use (Horne and Aiston 1924:89).

\section{Use of the Tula Adze}

Ethnographers and archaeologists have used a variety of terms to describe the function (i.e., chopping, scraping, chiseling, chipping, adzing, shaving, incising) of the tula adze. It was particularly suitable for working the hardwoods found in arid Australia, but was also used on softwoods (Akerman 2005; Cane 1992 : 24; Kamminga 1985 : 21). Ethnographers have noted that it was used to make and maintain a wide variety of wooden objects including weapons, spear-throwers, boomerangs, wooden dishes, bowls, and troughs (Horne and Aiston 1924:103, 107; McCarthy 1976:19; Roth 
1904 : 20). While the primary role of the tula adze was for woodworking, it was sometimes employed for other tasks. For example, usewear and residue studies by Cooper and Nugent (2009:221) indicate that plant processing, bone-working, and butchery were also undertaken using tula adzes. This result supports the ethnographic observations of Spencer and Gillen (1938:583-584) and Cane (1992:22), who noted that Central Australian and Western Desert Aborigines sometimes used tula adzes to chop through skin and bone during butchery.

While the tula adze may have performed several functions, it contains some design features that seem especially suited to the adzing of hardwood. The pronounced bulb of force gave the tula flake extra strength, while the twin curvature of the working edge intensified the efficiency of blows and helped distribute stresses evenly. Flenniken and White $(1985: 142)$ have also noted that the curved working edge prevented the adze bit from biting into the worked material, which could have caused breakage of the adze bit or the haft. The practice of hafting the tula flake deep in a resin on a curved wooden handle helped control the direction of the adze blow, which enhanced the overall efficiency of the tool.

A number of observers noted that operators usually held the tool in one or both hands and drawn back toward the operator, tilted at an angle of 30-45 degrees, with the ventral face nearest the object being worked (Gould et al. 1971:152; Mulvaney 1975 : 77; Noone 1949:112; Roth 1897:101; Spencer and Gillen 1969:637). This action could be employed for both scraping (where the stone was drawn across the wood in uniform strokes) and adzing (which involved a short, dynamic chopping motion) (Moore 2004:63). Like Noone (1949:111), Gould et al. (1971:152) noted that the implement was gripped close to the haft and the upper part of the handle acted as a counterbalance, "giving force and smoothness to the stroke."

\section{Maintenance of the Tula Adze}

The operator of a tula adze would continually resharpen the tula flake as he worked (Horne and Aiston 1924:107). Tula flakes found in archaeological contexts most frequently take the characteristic form of slugs, indicating that they have been worked and resharpened to the point of exhaustion. Tula flakes that reflect earlier stages of use are much less common, but archaeologists have been able to establish the phased and cumulative effects of use and resharpening on tula flake morphology. Campbell and Edwards (1966:195) asserted that the tula flake "shows consistent symmetry and shapeliness in form in all the varying stages of reduction." Subsequent studies have confirmed that tula flake reduction occurred in a predictable, organized sequence. The distal end of the flake was retouched and resharpened from the ventral surface onto the dorsal surface, producing heavily stepped retouch scars. If the initial shape of the prepared flake was relatively wide, resharpening tended to focus on the lateral extremities until a more regular, semi-discoidal shape was attained (Hewitt 1976:50). Otherwise, resharpening would proceed from the distal margin, gradually changing the edge shape from convex to straight, and continue until stepped retouch had considerably reduced the bulbar surface lengthwise, with the working edge only a centimeter or two from the platform (Clarkson 2007:116-122; Hiscock 1988:6566; Holdaway and Stern 2004 : 253; Veth et al. 2011 : 9). Occasionally tula flakes were removed from their haft after extensive use and reversed so that the opposite edge became the working face (Mulvaney 1975:82). 
Clarkson (2007:116-122) has demonstrated through a study of 66 retouched tula flakes from Wardaman Country in the Northern Territory that this relatively standardized reduction continuum is reflected in the variation of a number of tula attributes. With increased reduction, the curvature of the distal edge decreases. The percentage of the perimeter retouched also decreases because the unretouched edge represented by the platform forms a larger proportion of the perimeter (though if the adze is reversed in the haft and the platform is retouched, this trend is reversed). Clarkson's assemblage contained few adzes that he regarded as reflecting an early stage of use, but he noted that there was nearly a 50 percent reduction in weight between tulas in the middle and late stages of reduction. Based on this evidence, he suggested that up to 80 percent of weight may be shed during the use-life of a tula. By comparison with other small stone artifacts, this would imply careful, prolonged maintenance and a very long use-life.

\section{Transporting and Curating the Tula Adze or Flake}

Evidence suggests that tula adzes and flakes were transported in several ways. Multiple tula flakes were carried as replacement parts for personal use or in trade parcels (Horne and Aiston 1924:106; Noone 1949:111-112; Roth 1904:20; Tindale 1965:154, 160). The completed tula adze was also carried around for personal use, especially when it was the multifunctional tool of a mobile hunter (Cane 1992).

The caching (concealed storage) of tula flakes has been put forward as further evidence of their transportation. Caches of tula flakes have been reported at a number of Australian arid zone sites. The size and contexts of these caches vary significantly, giving rise to different interpretations. The Mucklandama Creek 6 cache discussed above contained 50 stone artifacts carefully stacked in a pit in a manner designed to prevent damage; these have been interpreted as unused adze flakes at various stages of manufacture (Hiscock 1988:62-65). Based on its close proximity to a trade route, the large quantity of tulas, and ethnographic evidence that tula flakes had been a trade item in the region, Hiscock (1988:66-67) suggested that it was a package intended for trade.

Hewitt (1976) has described three caches of stone artifacts from the Arcoona Plateau near Woomera, South Australia, that were partly or completely comprised of tula adze flakes. The largest, located near a complex of creek bed sites northeast of Lake Hanson, included 105 stone artifacts contained 43 prepared tula adze flakes. The cache also included smaller numbers of worn and reduced tulas, adzes of more amorphous type, and tools that were classified as burins and engravers. Hewitt considered that together these implements made up "a comprehensive woodworking kit" (1976:29). He concluded that the cache could have been a large trade parcel, but noted evidence that the site was an important center of Aboriginal activity during favorable climatic periods and may have been a locus for relatively large populations taking advantage of abundant food supplies. In these circumstances it was just as likely that the cache was a tribal stockpile and probably the product of a single specialized craftsman (Hewitt 1976:48-51).

A small cache of 12 stone artifacts was found east of the Arcoona Homestead. Eight of the artifacts were prepared tula adze flakes and the other four were retouched tools that were generally suitable for adzing, showing signs of previous use. All of the artifacts were made from the same exotic raw material. For this reason, Hewitt (1976:42-43, 49) interpreted the cache as a trade parcel. An even smaller cache of 
three tula flakes was identified near Phillip Ponds Homestead. The close similarity of these artifacts prompted Hewitt (1976:47-49) to claim that they were the work of a single craftsman and interpret them as the personal hoard of one man.

Hiscock (1988:68-69) has argued that all of these caches may be related to trading activities, but there is no compelling reason why a single interpretation must apply. There is no doubt that trade in tula flakes (though not complete tula adzes) occurred in some regions of Australia (Noone 1949:111-112; Roth 1904:20; Tindale $1965: 154,160)$, and it is likely that during the trading process large numbers of tula flakes were accumulated. The evidence also seems to be strong that on some occasions tula flakes were manufactured in numbers that exceeded immediate requirements and that these excess tulas were stored as valuable items that could be conveniently retrieved when needed for trade or as replacement parts for personal use (Horne and Aiston 1924:106).

\section{Discard of the Tula Adze}

The fact that the working components of tula adzes were rarely discarded until they had been reduced to the point where they could no longer function is a testament to the overall durability of the tool and the determination of operators to extract the maximum possible use-life from it. Evidence from archaeological spatial analyses suggests that the discard of used tula flakes was not random, but was organized in conjunction with a broader technological system. Most tula adzes, discarded as spent slugs, were concentrated close to the creek at Stud 1 and Stud 2 (Cochrane 1998, 1999). This discard pattern was distinct from other artifact categories, particularly those that reflected knapping waste or expedient tool use. It suggests that the use and maintenance of tula adzes occurred in a different spatial context from other activities and probably reflected a more specialized application of this technology. Veth (1987) has contrasted stone tool assemblages from two major Western Desert sites, Kadaru and Wantili, which are located only $15 \mathrm{~km}$ apart. Both are estimated to have in excess of 500,000 stone artifacts. At Kadaru there are over 1000 heavily reduced tula adzes but at Wantili they are rare. Veth suggested that the sites were occupied during different seasons and that Kadaru was a more sedentary base camp occupied by larger and more complex social groups that could engage more frequently in tasks such as specialized woodworking.

\section{THE TULA ADZE AS A RELIABLE DESIGN SYSTEM}

Having established how tula adzes were made, used, transported, and discarded, in this section we will now outline the extent to which the design of the tula adze conforms to each of the characteristics of a reliable design system, as originally defined by Bleed (1986). We will then look in more detail at the reasons for its implementation.

\section{Made and Maintained by a Specialist}

The production of a tula adze typically involved the input of a number of people. This division of labor ensured that the different components of the tula adze were made and assembled by people with particular expertise at that task. Good Triodia resins required several stages of manufacture; the techniques employed at each stage were the 
domain of gender- or age-based groupings. The efficient production of suitable tula flakes required advanced knapping skills, so this task tended to be given to practiced craftsmen. Individual specialists would produce tula adze flakes in bulk that were very standardized in their dimensions. These could be stockpiled or traded for other goods. Such factors led Tindale to describe adze flake manufacture as reflecting "a highly skilled, almost professional approach to implement making" (1965:160). The manufacturing of the wooden component of the tool, particularly if it was a spear-thrower, was also a specialized task. The production of wooden implements in the arid zone, whether they were to be used by women or men, tended to be conducted by older men who devoted a great deal of time to this role (Chewings 1936:7; Horne and Aiston 1924:105).

We will discuss the maintenance of the tula adze in more detail later in this section, but in general the tula adze was designed so that maintenance would not be very time-consuming. Unlike the initial manufacturing of the implement, most maintenance was not particularly specialized and could be conducted by the operator. It should however be added that the operator could often be regarded as a specialist in his own right.

\section{Good Craftsmanship}

In discussing the relevance of good craftsmanship to a reliable design system, Bleed (1986:739-740) emphasized the care paid to fitting parts and attention given to joints. These were consistent characteristics of tula adze production. Hurried methods that produced inferior resins (such as collection from ant nests) were eschewed in favor of more exacting methods that were known to result in the strongest possible adhesives. Once this resin had been applied, the flake was immersed very deeply into it, with close attention given to how the stone and wooden components were articulated.

Other examples of good craftsmanship employed in tula adze production include the use of very precise core reduction methods, percussion techniques, and retouching procedures in order to consistently produce flakes with the necessary features and dimensions. These procedures included measures such as the careful selection and alternation of indentors as a precaution against damaging the flake. Judging from ethnographic descriptions, the wooden component of the tool was always very well crafted, with artisans displaying good knowledge of how particular varieties of wood were best prepared and worked. Wooden spear-throwers in particular were often the product of very skilled labor, which could include polishing and decorating, as well as other detailed finishing work.

\section{Overdesigned Components}

A prominent feature of reliable design systems is that components of the system, especially the most crucial components, are designed to easily withstand the maximum stresses that will be encountered during use (Bleed 1986:739). There is very little ethnographic or archaeological evidence of tula adzes breaking; the stone component was most often discarded only after it was worn out. The most demanding function of tula adzes was to work hardwoods. In carrying out this function, a tool could potentially be damaged through the jarring of stone on wood or through the stone component biting into the worked material. Specific design features of the tula 
adze - the strong articulation of the flake with the handle and the twin curvature of the working edge-prevented these problems from occurring.

Overdesigned components are typically solid and sturdy. More so than any other Australian tool with a flaked stone component, tula adzes are characterized by the preferential selection of stone with high tensile strength and fracture toughness. Both the flaking method and the selection of flakes ensured that the working component had a strong, thick cross section, especially at the base. Handles were invariably manufactured from hardwood and were designed with thick, strong profiles.

\section{An Understressed Tool}

The factors that result in an implement being understressed mainly relate to how it is operated. In essence, an understressed tool is one that usually operates below its full capacity. An example is where the tool is typically used carefully, with precautions taken to guard against wastage or damage (Bleed 1986:739-743). Operation of the tula adze tended to be conducted in a precise, standardized manner. Users displayed a common awareness of the optimal angles and directions of adzing strokes. Design features in the tool tended to promote this efficient conduct. The length of the handle was generally longer than was strictly necessary, with most of it extending beyond the grip of the user. This acted as a counterbalance that aided the smoothness of the stroke. The curve in the handle also helped to control the angle and direction of the blow. The evidence from caches also indicates that stored tula adze flakes were stacked with great care to prevent breakage.

\section{Parallel Subsystems and Components}

Parallel subsystems and components come in two forms. Redundant components perform the same task simultaneously. Standby components operate as backups that can be brought into action if an equivalent component fails (Bleed 1986:740). The practice of hafting two tula flakes on each end of a handle is a very good example of a standby, parallel subsystem. It was also common for the operator of the tula adze to keep a collection of replacement tula flakes close at hand (Horne and Aiston 1924 : 106). In some cases, tula flakes appear to have been cached so that they could be retrieved and used when needed. There was a tendency for individuals to produce tula flakes that conformed to relatively standardized dimensions, a practice that typifies the nature of replacement parts in reliable design systems (Nelson 1991:66-67).

\section{Maintained and Used at Different Times}

Because the objective of reliable design systems is to maximize the availability of implements during times when they are needed, it is important that the need for maintenance not arise during usage in a way that significantly affects the performance of the task. The most common maintenance requirements of the tula adze was the need to resharpen the flake and, less frequently, replace it. Both of these practices usually occurred at various times during use sessions. Nelson has claimed that in reliable designs, "maintenance must occur in advance of use, not be integrated into the use timeframe" (1991:66-67). While it is true that these minor maintenance activities were embedded in the systemic use of tula adzes, we would argue that in the context 
they had a negligible impact on the availability of the implement to perform a task when it was needed. If there was no need to remove the flake, resharpening could be conducted in seconds. If a fire was nearby, the removal and resetting of flakes would not take much longer.

As far as more extensive maintenance is concerned, the evidence is thin, probably because the tula adze was designed not to fail. Spatial evidence of tula slugs discarded in concentrations, possibly within campsites, is not inconsistent with maintenance activities being conducted in conjunction with prolonged use sessions. There is ethnographic evidence from several arid zone contexts that woodworking in general was conducted by older men, so if the wooden component of a tula adze required repair it is possible this might have been conducted outside of the use context. In support of this, we have noted an example from the Arcoona Plateau where a cache contained a stockpile of woodworking equipment in various states of repair. The maintenance of wooden items in general appears to have often been a specialized task conducted separately from their use, especially among relatively large groups living in favorable conditions.

\section{Summary}

All of the factors discussed above imply relatively high costs of production and use. As Bleed (1986) pointed out, they are not costs that are incurred in every design system, so they reflect a decision to invest heavily in the reliability of the system. There are a number of conditions where this would be the optimal alternative. Design theory helps us discern which of these conditions are most likely to have influenced the design of the tula adze. Before considering this in detail, we will first discuss some other design categories that are relevant to tula adze production.

\section{OTHER DESIGN CATEGORIES}

As noted earlier in this article, Nelson (1991) defined three other design categories that, like Bleed's (1986) design systems, reflected different strategies for optimizing the effectiveness of tools depending upon the context of their use. According to Nelson, a "flexible" design allows a tool to be easily changed in form to meet multifunctional demands. A "versatile" design is one in which the tool has a generalized form capable of meeting a variety of needs. A "transportable" design enables the toolkit to be carried to the task.

The tula adze is a transportable item in the sense that most equipment used in the Australian arid zone was transportable. However, there is nothing in the design of the tool that reflects a particular effort to make it small or lightweight; on the contrary, hardwood was used and very long handles were manufactured to enhance the reliability of the implement. Consideration of the "flexible" and "versatile" design categories is more straightforward since each reflects a different strategy for achieving multifunctionality. We have discussed the multifunctionality of the tula adze. This seems to be the most important source of variability in tula adze design. In some contexts, usually when the tula flake is mounted at one or both ends of a plain handle, it is made and used as a specialized woodworking implement, with no other function contemplated. At the other extreme, the implement is more complex and is clearly designed to perform a broad range of tasks. These tasks apply to both the mounted 
stone components and the type of wooden handle. In terms of the stone components, often another retouched tool was mounted at the opposite end of the handle to the tula flake, enabling the implement to be used for a broader variety of tasks. The wooden handle also performed different tasks (i.e., as spear-thrower, container, or firesaw). In sum, the tula adze's multifunctionality was achieved through a versatile rather than a flexible design, since the different tasks could be performed without altering the form of the implement.

It follows that while the tula adze is always designed to be reliable, it is also sometimes designed to be versatile, depending upon the context of its production and use. It is inherently transportable, but its transportability may be most relevant in the context of its use as a multifunctional implement, where a single combined implement is more portable than a toolkit containing several specialized implements.

\section{INTERPRETING THE TULA DESIGN SYSTEM}

There are two broad types of conditions where a reliable design strategy is likely to be profitable. The first is where the implement is applied to highly specialized, repetitive activities, where both use and down times can be regularly predicted and scheduled. The second is where the cost of failure is very high, so the implement absolutely must work when needed. Design theory indicates that either or both of these conditions may encourage the development and implementation of reliable designs (Bleed 1986: 740-741).

We have noted that tula adzes were often applied to highly specialized, repetitive activities. However, the economic advantage of reliable designs in such conditions is that they maximize the availability of the tool by ensuring that maintenance activities can be conducted outside of the time that the tool was required for use. There is little evidence that the time spent conducting maintenance activities on the tula adze was of economic significance. The small amount of time needed to conduct maintenance activities was mainly embedded within use times.

We therefore consider it far more likely that the tula adze was manufactured according to reliable design specifications because it was to be used in situations where the cost of failure was very high. These situations are usually exemplified in hunting scenarios where the cost of failure is usually measured in terms of the inability to capture food that is essential for survival. It becomes more difficult to conceptualize high failure costs that apply to the operation of an implement designed to manufacture other implements. However, we will argue that the manufacture of the tula adze is an example of how a tool used to make others can be considered essential to survival.

\section{Environment of Tula Adze Use}

Akerman (2005) argues that the differences between archaeological and ethnographic distributions of tula adzes provide important clues about the conditions where tula adze use prospered. Ethnographic observations have tended to occur in environments that are not extremely arid and where the general economy has allowed a more sedentary existence. Akerman noted that other features of these locales were the use of large, well-made grindstones and storage of grains and seeds in large wooden recep- 
tacles. He therefore suggested that tula adzes were integral components of economies that emphasized the collection and storage of seasonally abundant grains and seeds and that their most important use was in manufacturing the large wooden vessels that enabled food storage on a large scale. The presence of tula adzes in Western Desert archaeological sites but their apparent absence at the time of European contact is interpreted as evidence of a shift in economic strategy in this region to one of greater mobility some time during the late Holocene.

There could be direct economic costs of failure in producing wooden items in sufficient numbers if they were linked to food production or storage. Akerman's hypothesis could be one example of this, although it would only apply if the lack of suitable wooden storage containers had a detrimental effect on the food supply. Bowdler (1981:108) has suggested that hafted adzes may have enabled more efficient production of women's digging sticks. A similar argument could be made for the production of other wooden items that were vital in the food quest, such as spears, spearthrowers, boomerangs, and water containers. In this way the tula adze was important in the acquisition of food from both hunting and gathering.

Many of the items used both in hunting and gathering may themselves have been products of reliable designs. If this emphasis on producing reliable equipment is to be seen as an investment against the high cost of failure, then we would suggest two possible scenarios. The first is that there was a very strong dependence on foods that were only seasonally available and that sufficient amounts of extractive equipment needed to be ready before the harvest because there would be little time for tool manufacturing or maintenance during the harvest. The second is that populations expanded and contracted regularly, with large groups creating a high, short-term demand for food and hence the need for suitable extractive and hunting equipment. A combination of these scenarios, with groups aggregating and dispersing in accordance with the seasonal distribution of resources, is also possible.

However, there are some aspects of the ethnographic record that stand at odds with the notion that the high production costs of the tula adze were a direct investment into the security of the food supply. The tula adze could be used to manufacture wooden implements quickly, but workers apparently emphasized that these implements be of high quality and pleasing to the eye. The tula adze was sometimes used for hours on end to carve flutes and various forms of decoration (Roth 1897:101; 1904:20). Spencer and Gillen (1912:380-381) noted that this attention to detail did not actually make the items more useful, but that the graceful outlines, the high levels of symmetry, and the intricate decorations lent them a highly impressive appearance.

Furthermore, while ethnographic reports of tula adze usage in the Western Desert are not entirely consistent, we are less convinced than Akerman that tula adzes were not used in this region in recent times. Recent use of tula adzes in the Western Desert does seem to have been less intense than that which occurred in other parts of the arid zone and occurred concurrently with the use of other types of adzes (Cane 1992:2223; Gould et al. 1971:151-154; Tindale 1965 :138). This variability in contexts of tula adze use must be taken into account when considering the question of why its design was chosen ahead of less costly alternatives.

Veth et al. (2011) recently summarized evidence of the chronology of the tula adze and concluded that the earliest tula adzes appeared at about 3500-3700 B.P. in Central and Western Australia. They pointed out that the appearance and proliferation of tulas in Central and Western Australia between 3700 and 2000 B.P. coincided with the in- 
tensification of El Niño Southern Oscillation (ENSO) conditions. The effect of these conditions was greater aridity in Australia, but in Central Australia the most marked change was increasing climatic variability with occasional significant rainfall events. Veth et al. (2011:12) argued that these changed conditions prompted economic changes in desert societies, and that the appearance and dispersal of tulas was connected with this.

Veth et al. (2011:12) reasoned that the economic implications of greater climatic variability were greater resource patchiness and reduced resource predictability. The likely social responses to this included changes to group size and the size of territories, changes in trade and exchange relationships, and greater residential mobility. The introduction of the tula adze was seen as part of the technological response to the need for greater mobility, because it provided "an extreme example" of a curated, multipurpose tool (Veth et al. 2011:12). Clarkson (2007) also regarded the development of the tula as a response to increased mobility, risk, and uncertainty, but unlike Veth et al. (2011), he considered that both points and tulas were designed for "semi-specialised tasks."

Just as Akerman's hypothesis emphasizes the use of tula adzes in relatively specialized, sedentary contexts and underplays its significance as a multipurpose tool in more mobile contexts, Veth et al.'s (2011) hypothesis does the opposite. We believe that the coincidence of tula adze introduction and proliferation with a time of greater climatic variability is significant, but that the technological response to this variability was probably more complex than a simple shift to more compact equipment.

It may also be an oversimplification to merely describe the change in settlement strategies as one of greater mobility. Averaged over 2000 years, this may be the case, but it does nothing to describe the important variability in settlement strategies that would have occurred over this timeframe. It would probably be more accurate to suggest that settlement strategies became more flexible, enabling populations to quickly adapt to both short-term and long-term changes in resource distribution (Hewitt 1976:50-51).

\section{Trade-Dependent Economies and the High Cost of Failure}

One of the keys to surviving in unpredictable environments is cooperative behavior (Strehlow 1970; Yengoyan 1976). There is ample ethnographic and ethnohistoric evidence that by the time of European contact, intricate trade and exchange networks had been established throughout the arid zone, linking it to the coastal regions (e.g., Allen 1997; Kaberry 1939:166-174; McBryde 1987; McCarthy 1939; Mulvaney 1976; Watson 1983:29-38). These networks consisted of commonly exploited trade routes that were spread like arteries throughout the continent. At particular nodes on these routes, regular large-scale meetings occured. Smaller meetings were also often arranged between neighboring groups. Goods would be bartered, gifts and customs exchanged, ceremonies conducted, and disputes resolved at these meetings. If a highly valued commodity was available within the territory of a particular group, it was frequently traded over long distances, either as a raw material or as manufactured goods. Among many groups, individuals held distinct roles as messengers, facilitators, agents, or partners in trade relationships. 
If a region lacked rare natural resources that could be exploited as valuable trade items, its people could still find ways to benefit from these trade networks. For example, in Central Australia, commodities such as troughs, shields, spears, spearthrowers, and boomerangs were valued according to where they were manufactured rather than the origin of the wood. This was because the tradesmen from particular areas built up a reputation for being the best producers of particular items. These values were reinforced by myths about the spiritual origins of the items or their methods of manufacture (McCarthy 1939: 428-430, 171-172).

While it has been difficult for archaeologists to date precisely the formation of these complex trading networks, many archaeologists have argued that significant changes in social and demographic relationships occurred throughout mainland Australia about 4000 years ago (Beaton 1982: 57; Bowdler 1981:109-110; Lourandos 1985, 1993, 1997:305-321; Morwood 1981:369-372; Ross 1981; Smith 1986; Veth 1989). This argument is based on broadly concurrent changes in the archaeological record that happened at this time, including:

1. marked technological changes, especially the technological shift from the Core Tool and Scraper Tradition to the Small Tool Tradition;

2. changes in rock art styles to styles that reflect social and ceremonial relationships between groups;

3. more intensive occupation of marginal environments, including the arid zone;

4. generally higher discard rates of stone artifacts;

5. the introduction of communal ceremonial activities; and

6. greater complexity of burial processes.

Taking all of these factors into account, we believe that from around the time of the ENSO intensification, most arid zone groups underwent a transition to what were essentially trade-dependent economies. What we mean by this is that the necessities of life (i.e., food and the means to acquire it, water, medicines, and protection from the elements) were not obtained continuously and solely through the efforts of autonomous groups, but were supplemented significantly through the ability to negotiate with others. This negotiation would have taken three main forms (McCarthy 1939:171-175). The first may be described as pure trade, where a group will collect or produce an amount of a commodity that is surplus to their needs and trade it with another party for a commodity that is in short supply. The second form is the exchange of knowledge, such as information about innovations that have been used to successfully adapt to new environmental conditions. The third form is alliances, fostered through processes such as reciprocal gift exchange, which essentially enable groups to be more flexible in their territorial relationships. This allows the economic potential of a region to be maximized and provides a form of insurance against localized adversities.

The evidence strongly suggests that all three of these forms of exchange were fundamental parts of the arid zone economy during the late Holocene. When we seek out possible circumstances that would warrant the time investment involved in the manufacture of the tula adze-circumstances where failure during use was simply not an option-we need to consider what might be regarded as failure in a tradedependent economy. In this context, long-term threats to survival lie not only in the day-to-day results of the food quest, but also revolve around more lingering questions about the health of trade relationships and alliances. As these systems developed, 
experience would have taught arid zone groups that failure was not an option when it came to both the quantity and quality of exchange goods. The manufacturing of tula adzes in accordance with reliable design principles minimized the risk that such a failure would occur.

While groups may have varied their settlement strategies over the last four millennia in response to climatic fluctuations, implying greater or lesser mobility, the important role of trade in their economy would have remained a constant. The ethnographically observed variability in tula adze production and use reflects this. Where it is used by more mobile people, it is incorporated as part of a multipurpose implement. With more sedentary people, it is a more specialized implement. In both cases, it is a reliably designed implement with high production costs and the most likely return on these costs is the ability to manufacture not only items utilized in the ongoing food quest, but more significantly, high-quality, valuable trade goods in a prompt and efficient manner. The long-term survival of groups in the variable, unpredictable, and often harsh climate of the Australian arid zone was highly dependent on the cooperative relationships that populations could forge with one another. The design of the tula adze (and its proliferation and persistence through time) should be viewed as a technological adaptation to the requirements of these general socioeconomic conditions.

\section{CONCLUSION}

The management of environments and landscapes ... is as much a sociocultural as an ecological phenomenon.

—Lourandos and Ross 1994:59-60

Historically, theories that are founded on optimization models have tended to be developed and utilized by archaeologists with a strong environmental or economic perspective on the causes of cultural change. Like many contemporary archaeologists, we have argued that social structures are not just mechanisms that are used to adapt to an external environment, but are also a part of the environment that constrains human behavior (Cochrane et al. 2013). Our use of design theory in this article reflects this view. The time invested in designing and manufacturing the tula adze to be a reliable implement can be interpreted as an optimal solution to particular needs of arid zone Aboriginal populations in the late Holocene, but only if it is recognized that the equation of economic inputs and outputs is a complex one. Not only was the tula adze advantageous in the manufacture of items for personal or group use but it had much wider benefits in the production of trade items. It may have been expensive to devote large amounts of time to the production of high-quality trade goods, but in the long run it also provided an indirect means for securing the food supply in an unpredictable environment.

\section{ACKNOWLEDGMENTS}

For helpful comments and suggestions during the preparation of this article our sincere thanks to Simon Holdaway, Peter White, and Robin Torrence. We also thank John Webb and Marion Domanski for their technical assistance. 


\section{REFERENCES CITED}

Aiston, GEORge

1928 Chipped stone tools of the Aboriginal tribes east and north-east of Lake Eyre South Australia. Papers and Proceedings of the Royal Society of South Australia, 123-131.

1929 Method of mounting stone tools on koondi. Tribes of east and north-east of Lake Eyre. Proceedings of the Royal Society of Tasmania, 44-46.

Akerman, Kim

2005 The efficiency of tula adze-flake production- a contrary view, with comments on the suggested use of tula adzes. Antiquity 79:305, Project Gallery.

Allen, Harry

1997 The distribution of large blades: Evidence for recent changes in Aboriginal ceremonial exchange networks, in Archaeology and Linguistics: Aboriginal Australia in Global Perspective: $357-$ 376, ed. Patrick McConvell and Nicholas Evans. Oxford: Oxford University Press.

BeAton, John M

1982 Fire and water: Aspects of Australian Aboriginal management of cycads. Archaeology in Oceania $17: 51-58$.

Bleed, Peter

1986 The optimal design for hunting weapons: Maintainability or reliability. American Antiquity $51: 737-747$.

2002 Cheap, regular and reliable: Implications of design variation in Late Pleistocene Japanese microblade technology, in Thinking Small: Global Perspectives on Microlithization: 95-102, ed. Robert G. Elston and Steven L. Kuhn. Archaeological Papers of the American Anthropological Association No. 12. Arlington: American Anthropological Association.

BOWDLER, SANDRA

1981 Hunters in the highlands: Aboriginal adaptations to the eastern Australian uplands. Archaeology in Oceania 16:99-111.

Campbell, Thomas, and Robert Edwards

1966 Stone implements, in Aboriginal Man in South and Central Australia, part 1:159-220, ed. Bernard C. Cotton. Adelaide: South Australian Government Printer.

CANE, SCOTT

1992 Aboriginal perspectives of their stone tool technology: A case study from the western desert, Australia. Australian Archaeology 35 : 11-31.

Chewings, Charles

1936 Back in the Stone Age: The Natives of Central Australia. Sydney: Angus and Robertson.

Clarkson, Chris

2007 Lithics in the Land of the Lightning Brothers: The Archaeology of Wardaman Country, Northern Territory. Terra Australis 25. Canberra: ANUE Press.

Cleland, John B.

1957 Australia: Ethno-ecology. Our natives and the vegetation of southern Australia. Mankind 5(4) : 149-162.

Cochrane, Grant W. G.

1998 Toward an Unfamiliar Past: New Approaches to Spatial Analysis at Stud Creek, Northwest NSW. Unpublished B.A. (Hons) thesis, La Trobe University, Bundoora.

1999 Spatial Analysis of Stud 2. Unpublished report, La Trobe University, Bundoora.

Cochrane, Grant W. G., Trudy Doelman, and Lyn Wadley

2013 Another dating revolution for prehistoric archaeology? Journal of Archaeological Method and Theory 20(1): 42-60.

Cooper, Jane L., and Suzanne J. Nugent

2009 Tools on the surface: Residue and use-wear analyses of stone artefacts from Camooweal, northwest Queensland, in Archaeological Science Under a Microscope: Studies in Residue and Ancient DNA Analysis in Honour of Thomas H Loy: 207-227, ed. Michael Haslam. Terra Australis 30. Canberra: ANUE Press.

Doelman, TRUdy

2005 Patterns among the masses: An approach to the analysis of a quarry assemblage. Archaeology in Oceania $40: 50-61$. 
2008 Time to Quarry: The Archaeology of Stone Procurement in Northwestern New South Wales, Australia. Oxford: BAR International Series 1801.

Doelman, Trudy, John Webb, and Marion Domanski

2001 Source to discard: Patterns of lithic raw material procurement and use in Sturt National Park, northwestern New South Wales. Archaeology in Oceania 36:15-33.

EERKENS, JELMER W.

1998 Reliable and maintainable technologies: Artefact standardization and the Early to Later Mesolithic transition in Northern England. Lithic Technology 23:42-53.

Eerkens, Jelmer W., ANd Robert L. Bettinger

2001 Techniques for assessing standardization in artifact assemblages: can we scale material variability? American Antiquity 66:493-504.

ETHERIDGE, ROBERT

1891 Notes on Australian Aboriginal stone weapons and implements. Proceedings of the Linaean Society of New South Wales 6:31-43.

Feltz, Carol J., and G. Edward Miller

1996 An asymptotic test for the equality of coefficients of variation from k populations. Statistics in Medicine 15:647-658.

Flenniken, J. Jefrrey, and J. Peter White

1985 Australian flaked stone tools: A technological perspective. Records of the Australian Museum $36: 131-151$.

FloOd, JOSEPHINE

1993 Archaeology of the Dreamtime. Sydney: Collins.

GOULD, Richard A.

1978 The anthropology of human residues. American Anthropologist 80:815-835.

Gould, Richard A., Dorothy A. Koster, and Ann H. L. Sontz

1971 The lithic assemblage of the Western Desert Aborigines of Australia. American Antiquity $36: 149-169$.

HAYden, BRIAN

1979 Palaeolithic Reflections: Lithic Technology and Ethnographic Excavation among Australian Aborigines. Canberra: Australian Institute of Aboriginal Studies.

HewitT, RONALD

1976 Aboriginal adze stone hoards found on the Arcoona Plateau near Woomera, South Australia. Australian Archaeology 4:14-52.

Hiscock, Peter

1988 A cache of tulas from the Boulia District of Western Queensland. Archaeology in Oceania $23: 60-70$.

Holdaway, Simon, and Matthew Douglass

2012 A twenty-first century archaeology of stone artifacts. Journal of Archaeological Method and Theory 19:101-131.

Holdaway, Simon J., Justin Shiner, and Patricia C. Fanning

2004 Hunter-gatherers and the archaeology of discard behavior: An analysis of surface stone artefact scatters from Sturt National Park, New South Wales, Australia. Asian Perspectives 43:34-72.

Holdaway, Simon J., and Nicola Stern

2004 A Record in Stone: The Study of Australia's Flaked Stone Artefacts. Canberra: Aboriginal Studies Press.

Horne, George, And George Aiston

1924 Savage Life in Central Australia. London: Macmillan and Co., Ltd.

Kaberry, Phyllis M.

1939 Aboriginal Woman: Sacred and Profane. London: Routledge.

KAMMinga, Johan

1982 Over the Edge: Functional Analysis of Australian Stone Tools. Occasional Papers in Anthropology 12. St. Lucia: Anthropology Museum, University of Queensland.

1985 The pirri graver. Australian Aboriginal Studies 2:2-25. 
Latz, Peter K.

1995 Bushfires and Bushtucker: Aboriginal Plant Use in Central Australia. Alice Springs: I. A. D. Press.

LOURANDOS, HARRY

1985 Intensification and Australian prehistory, in Prehistoric Hunter-gatherers: The Emergence of Cultural Complexity: 385-423, ed. T. Douglas Price and James A. Brown. Sydney: Academic Press.

1993 Hunter-gatherer cultural dynamics: Long- and short-term trends in Australian prehistory. Journal of Archaeological Research 1:67-88.

1997 Continent of Hunter-gatherers. New Perspectives in Australian Prehistory. Cambridge: Cambridge University Press.

Lourandos, Harry, and Annie Ross

1994 The great "intensification debate": Its history and place in Australian archaeology. Australian Archaeology 39:54-63.

McBryde, IsABEL

1987 Goods from another country: Exchange networks and the people of the Lake Eyre basin, in Australians, A Historical Library, vol. 1: Australians to 1788:252-273, ed. D. John Mulvaney and J. Peter White. Sydney: Fairfax, Syme and Weldon.

MCCARThy, Frederick D.

1939 "Trade" in Aboriginal Australia and "trade" relationships with Torres Strait, New Guinea and Malaya. Oceania 9:405-438; 10:80-104, 171-195.

1976 Australian Aboriginal Stone Implements. Sydney: Museum Trust.

MCNiven, IAN

1993 Tula adzes and bifacial points on the east coast of Australia. Australian Archaeology 36:22-33.

MoOre, Mark W.

2004 The tula adze: Manufacture and purpose. Antiquity 78:61-73.

Morwood, Michael J.

1981 Archaeology of the Central Queensland Highlands: The stone component. Archaeology in Oceania 16:1-52.

1984 The prehistory of the Central Queensland Highlands. Advances in World Archaeology 3:325-380.

Mountford, Charles P.

1941 An unrecorded method of manufacturing wooden implements by simple stone tools. Transactions of the Royal Society of South Australia 65:312-316.

Mulvaney, D. John

1969 The Prehistory of Australia. London: Thames and Hudson.

1975 The Prehistory of Australia. London: Penguin.

1976 "The chain of connection": The material evidence, in Tribes and Boundaries in Australia: 121132, ed. N. Peterson. Canberra: Australian Institute of Aboriginal Studies.

Nelson, Margaret C.

1991 The study of technological organization. Archaeological Method and Theory 3:57-100.

NoOne, Herbert V. V.

1949 Some implements of the Australian Aborigines with European parallels. Man 49:111-114.

Pitman, Heidi T.

2010 Pointless Spinifex? An Investigation of Indigenous Use of Spinifex throughout Australia. Unpublished B. Archaeology (Hons) thesis, Dept. of Archaeology, Flinders University, Adelaide.

Ross, ANNIE

1981 Holocene environments and prehistoric site patterning in the Victorian Mallee. Archaeology in Oceania $16: 145-155$.

Roth, WALTER E.

1897 Ethnological Studies Among the North-West-Central Queensland Aborigines. Brisbane: Government Printer.

1904 Domestic implements, arts and manufactures. North Queensland Ethnography Bulletin No. 7.

SHERIDAN, Graham

1979 Tulas and Triodia. Unpublished M.A. Thesis, Australian National University, Canberra.

Smith, Michael A.

1986 The antiquity of seedgrinding in central Australia. Archaeology in Oceania 21 :29-39. 
Sмiтh, Moya A.

2006 Characterising late Pleistocene and Holocene stone artefact assemblages from Puritjarra rockshelter: A long sequence from the Australian desert. Records of the Australian Museum $58: 371-410$.

SPENCER, BALDWIN

1928 Wanderings in Wild Australia, Vol. II. London: MacMillan and Co. Ltd.

Spencer, Baldwin, and Francis J. Gillen

1912 Across Australia. London: Macmillan and Co. Ltd.

1938 The Native Tribes of Central Australia, 2nd ed. New York: Dover Publications.

1969 The Northern Tribes of Central Australia, 2nd ed. Oosterhout: Anthropological Publications.

Strehlow, Theodor G. H.

1970 Geography and the totemic landscape in Central Australia: A functional study, in Australian Aboriginal Anthropology: 92-140, ed. Ronald M. Berndt. Nedlands: University of Western Australia Press.

Sullivan, Marjorie E., and Stewart Simmons

1979 Silcrete: A classification for flaked stone artefact assemblages. The Artefact 4:51-60.

Thomson, Donald F.

1964 Some wood and stone implements of the Bindibu tribe of central Western Australia. Proceedings of the Prehistoric Society 30:400-422.

Tindale, Norman B.

1965 Stone implement making among the Nakako, Ngadadjara, and Pitjandjara of the Great Western Desert. Records of the South Australian Museum 15:131-164.

TORRENCE, RoByn

2001 Hunter-gatherer technology viewed at different scales, in Hunter-Gatherers: An Interdisciplinary Perspective: 73-98, ed. Catherine Panter-Brick, Robert Layton, and Peter Rowley-Conwy. Cambridge: Cambridge University Press.

Veth, Peter

1987 Martujarra prehistory: Variation in arid zone adaptations. Australian Archaeology 25:102-111.

1989 Islands of the interior: A model for the colonization of Australia's arid zone. Archaeology in Oceania 24:81-92.

Veth, Peter, Peter Hiscock, and Alan Williams

2011 Are tulas and ENSO linked in Australia? Australian Archaeology 72:7-14.

Watson, Pamela L.

1983 This Precious Foliage: A Study of the Aboriginal Psycho-active Drug Pituri. Sydney: University of Sydney.

Webb, John A., And Marion Domanski

2008 The relationship between lithology, flaking properties and artefact manufacture for Australian silcretes. Archaeometry 50:555-575.

WitTER, DAN C.

1992 Regions and Resources. Unpublished Ph.D. thesis, Department of Prehistory, Research School of Pacific Studies, Australian National University, Canberra.

WopfNer, HeLmut

1978 Silcretes of northern South Australia and adjacent regions, in Silcrete in Australia: 93-141, ed. Trevor Langford-Smith. Armidale: University of New England.

Yengoyan, Aram A.

1976 Structure, event and ecology in Aboriginal Australia: A comparative viewpoint, in Tribes and Boundaries in Australia: 121-132, ed. Nicolas Peterson. Canberra: Australian Institute of Aboriginal Studies.

\section{ABSTRACT}

The tula adze is a distinctive composite tool that was used in the Australian arid zone during the late Holocene. In this paper we use design theory to investigate why this particular tool form was so pervasive across time and space. Design theory provides a rational means for classifying tool designs and for determining why particular tool design 
classes were employed over others. We draw upon ethnographic and archaeological evidence to characterize the design of the tula adze and conclude that it is consistently the product of a "reliable" design strategy. We further determine that the high cost of a reliable design was chosen because the tula adze was employed in situations where failure could not be tolerated. Specifically, we argue that an important role of the tula adze was to manufacture wooden goods for not only personal use but more significantly for trade. The quantity and quality of these goods had an extremely strong bearing on the economic sustainability of arid zone Aboriginal groups. KeYwords: design theory, stone tools, tula adze, Australia, paleoenvironments. 